\title{
AN INVESTIGATION CONCERNING THE FOOD OF CERTAIN BIRDS.
}

\author{
BY JOHN HAMMOND, B.A. \\ (School of Agriculture, Cambridge.)
}

\section{Part I. General.}

THE investigation to be described was instigated by Professor Wood and Mr Warburton of the School of Agriculture, Cambridge, in the beginning of the year 1911. Its object was to determine whether or not certain birds were harmful to agriculture; as some naturalists and others considered them to be distinctly beneficial, while farmers were complaining of the damage done to their crops.

The first investigation concerning the food of birds in this country was made by Gurney and Russell (5) ${ }^{1}$, who in $188 j$ examined the crops of sparrows killed at all seasons of the year. Since that time there have been comprehensive investigations by Gilmour (4) on woad pigeons, rooks and starlings; by Thorpe and Hope (19) on the black-headed gull; by Newstead (12) on the food of many species; and by Collinge ( 2 and 3 ) on the rook and starling.

The method adopted in this investigation was the examination of the stomach contents, together with a collection of field notes concerning each bird. The importance of this combination has been emphasized by Judd (9) and Palmer (14), who have also put forward another method; that of experiment on birds lately captured. The latter however has not been attempted in this investigation.

The various points taken into consideration when beginning were as follows:-

(1) That the examination of the stomach contents ought to be continued throughout the year, as the conditions (barvest, seed-time, ploughing, etc.) would vary considerably.

(2) That the district from which the birds to be investigated came should be extensive but not too wide. If all were taken from a small area, local conditions would be too prominent; whereas, if birds were

1 See List of References at end of this article. 
obtained from the whole of Grent Britain, the variations in climate (and consequently in dates of seeding and harvest) would prevent a clear idea being obtained of the changes in the food materials that occurred from month to month.

(3) Thut field notes ought to be taken when the birds were killed, the following facts being mentioned: (a) name and address of sender, (b) date and time of day, (c) exact locality in which the bird was killed, (d) weather, on account of its influence on insect life; $(e)$ special notes, if the bird was doing any particular injury.

With the co-operation of many members of the Norfolk and Norwich Naturalists' Society, as well as others resident in Norfolk, Essex and Cambridgeshire, this object has been carried out.

I have here to express my sincere thanks to all those who sent birds and especially to $\mathrm{Mr} \mathrm{J}$. A. Christie, who sent me a large number.

The following is a list of the names of those who have sent birds :Norfolk:-Messrs J. H. Bugden, Suffield-E. Case, Kettlestone-J. A. Christie, Framingham Pigot-J.H.Gurney, Keswick-Q. E. Gurney, Northrepps-B. Hammond, Brampton-R. Lawrence, FelthorpeH. le Strange, Hunstanton-B. B. Sapwell, Aylsham-C. B. Ticehurst, Lowestoft and J. H. Walter, Drayton.

Essex:-Miss K. M. Courtauld, Colne Engaine-Messrs H. S. Bell, Earls Colne-G. Brunwin, Great Bardfield and H. W. Page, Boxted. Cambridgeshire:-Mr F. N. Webb, Babraham, and Mr A. J. Burgess, Gravel Hill Farm, Cambridge.

My thanks are also due to $\mathrm{Mr}$ Warburton, who has helped me considerably both in the identification of insects and also in the general management; to Mr Scott, curator in Entomology in the University of Cambridge, for help in identifying insects, and also for the use of a large collection of insects for reference; and to the Department of Agriculture, Cambridge, for defraying the expenses of the investigation.

To state briefly, the method of working was as follows:-The birds when killed were sent in with field notes, giving the particulars before mentioned, and on arrival they were cut open and examined. In both species of birds systematically investigated there was no crop, and consequently most of the material came from the gizzard and proventriculus, although a little was sometimes found in the oesophagus. Below the gizzard there was not much that could be identified, so that as a rule the intestines were not examined. The method of separating the stomach contents was essentially the same as that adopted by 


\section{Investigation concerning the Food of certain Birds}

Newstead (12). The materials were washed out into a white porcelain dish by a jet of water and then washed and roughly separated by a process of sedimentation; afterwards each separate article was picked out with forceps and placed in a watchglass. These pieces, after being identified and their numbers counted, were mounted on a sheet of cardboard.

The numbers of the insects given in the records below were arrived at by counting those parts which were best preserved. The materials were divided up, with reference to Agriculture, into three main divisions -injuries, benefits and neutral-and the two former subdivided into vegetable and animal matter, thus following roughly the classification of Gilmour (4) and more closely that adopted lately by Mason and Lefroy (11). It was often difficult to decide under which heading a certain insect should be placed, for in most cases the species was not determined. Many genera have been classed together owing to the difficulty in identifying them exactly from the remains; thus Carabid beetles are all classed together and placed in the "injurious" column, because a large number are carnivorous. In a few cases the genus is only approximate; for example, any Gastropod of the Helix type has been referred to as Helix. The majority of the insects and weed'seeds were identified by comparing them with collection specimens, the grain by the structure of the husk and form of the starch grains, and the leaves by the appearance of the epidermis and position of the girders and ribs in transverse section.

\section{Part II. The Starling.}

The starling appeared to be a suitable bird for investigation because a wide difference of opinion exists concerning its value to Agriculture. Slater (17) states that it is "normally one of the most useful birds we have"; while Archibald (1) has noted that it seems to be changing its habits for the worse, so far as the taking of grain is concerned; again, in a leaflet of the Board of Agriculture (20) the view is expressed that its usefulness far more than outweighs the occasional harm done. Of late there have been many complaints by farmers concerning the damage done by it, resulting in the recent deletion of the bird's name from the protected list in the county of Middlesex and the action against it by the West Somerset Farmers' Club.

Accounts of investigations concerning the food of the starling have been published by Gilmour (4), who, examining birds from one estate 
in Fifeshire, came to the conclusion that they were beneficial; by Newstead (12), who investigated particularly the food of the young; by Kelso (10), who showed that seed wheat was taken; and by Collinge (3) who states that "the food during the first six months of the year was distinctly of an insectivorous character in the vicinity of the city of Birmingham."

\section{TABLE I.}

This table shows the localities where the birds were killed each month. It may be objected, from what follows below that the localities were not represented proportionately to the number of birds frequenting those localities. To me it seems probable that the numbers are more or less approximate, as a natural result of the means by which they were obtained. In support of this, field notes concerning the places that the birds frequented were in general agreement with the numbers given in the table below. It should be pointed out here that no attempt was made to investigate the effect of the bird on fruit growing.

Table I. Starlings.

Number and localities of birds examined each month.

\begin{tabular}{|c|c|c|c|c|c|c|c|c|c|c|c|c|c|}
\hline Locality & : & $\begin{array}{l}\text { 멈 } \\
\text { ప్ర }\end{array}$ & 范 & 茎 & $\stackrel{\Xi}{g}$ & 롬 & $\stackrel{0}{\overrightarrow{4}}$ & 营 & ठ̊̊ & $\frac{\dot{0}}{z}$ & 迎 & 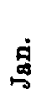 & 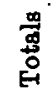 \\
\hline 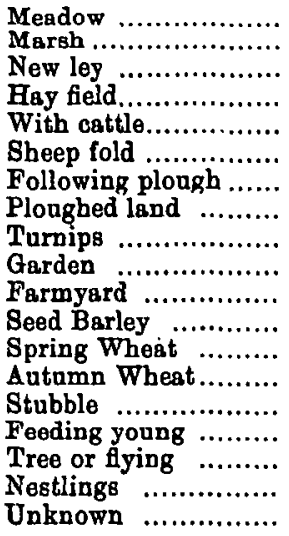 & $\begin{array}{l}4 \\
1 \\
2 \\
0 \\
0 \\
2 \\
2 \\
1 \\
0 \\
1 \\
1 \\
0 \\
1 \\
2 \\
0 \\
0 \\
0 \\
0 \\
0\end{array}$ & $\begin{array}{l}8 \\
2 \\
1 \\
0 \\
0 \\
1 \\
1 \\
2 \\
0 \\
0 \\
1 \\
1 \\
0 \\
0 \\
0 \\
0 \\
1 \\
0 \\
6\end{array}$ & $\begin{array}{r}7 \\
0 \\
0 \\
0 \\
0 \\
1 \\
1 \\
0 \\
0 \\
1 \\
0 \\
5 \\
13 \\
0 \\
0 \\
0 \\
1 \\
0 \\
0\end{array}$ & $\begin{array}{r}9 \\
\mathbf{2} \\
0 \\
0 \\
0 \\
0 \\
0 \\
0 \\
0 \\
0 \\
0 \\
0 \\
0 \\
0 \\
0 \\
2 \\
2 \\
12 \\
2\end{array}$ & $\begin{array}{l}7 \\
0 \\
0 \\
5 \\
0 \\
1 \\
0 \\
0 \\
0 \\
0 \\
0 \\
0 \\
0 \\
0 \\
0 \\
2 \\
0 \\
\mathbf{5} \\
\mathbf{3}\end{array}$ & $\begin{array}{l}8 \\
0 \\
0 \\
0 \\
6 \\
0 \\
0 \\
0 \\
1 \\
0 \\
1 \\
0 \\
0 \\
0 \\
0 \\
0 \\
0 \\
0 \\
0\end{array}$ & $\begin{array}{l}0 \\
0 \\
0 \\
2 \\
6 \\
0 \\
0 \\
0 \\
0 \\
0 \\
0 \\
0 \\
0 \\
0 \\
0 \\
0 \\
1 \\
0 \\
2\end{array}$ & $\begin{array}{l}4 \\
0 \\
0 \\
0 \\
0 \\
0 \\
0 \\
0 \\
0 \\
0 \\
0 \\
0 \\
0 \\
0 \\
4 \\
0 \\
1 \\
0 \\
4\end{array}$ & $\begin{array}{l}0 \\
0 \\
0 \\
0 \\
0 \\
0 \\
2 \\
1 \\
0 \\
5 \\
0 \\
0 \\
0 \\
0 \\
0 \\
2 \\
0 \\
5 \\
0 \\
0\end{array}$ & $\begin{array}{r}0 \\
0 \\
0 \\
0 \\
0 \\
2 \\
0 \\
0 \\
2 \\
0 \\
0 \\
0 \\
0 \\
17 \\
1 \\
0 \\
1 \\
0 \\
2\end{array}$ & $\begin{array}{r}0 \\
1 \\
0 \\
0 \\
0 \\
0 \\
0 \\
8 \\
0 \\
0 \\
0 \\
0 \\
0 \\
12 \\
0 \\
0 \\
3 \\
0 \\
0\end{array}$ & $\begin{array}{l}6 \\
0 \\
1 \\
0 \\
0 \\
0 \\
0 \\
4 \\
0 \\
0 \\
0 \\
0 \\
0 \\
2 \\
0 \\
0 \\
5 \\
0 \\
0\end{array}$ & $\begin{array}{r}53 \\
6 \\
4 \\
7 \\
12 \\
9 \\
5 \\
10 \\
8 \\
2 \\
3 \\
6 \\
14 \\
33 \\
7 \\
4 \\
20 \\
17 \\
19\end{array}$ \\
\hline Totals.............. & 17 & 24 & $\cdot 29$ & 29 & 23 & 16 & 11 & 13 & 15 & 25 & 19 & 18 & 239 \\
\hline
\end{tabular}


384 Investigation concerning the Food of certain Birds

\begin{tabular}{|c|c|c|c|c|}
\hline 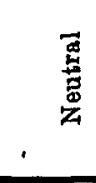 & 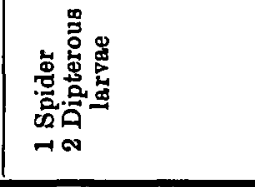 & 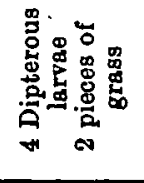 & 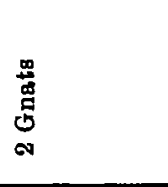 & 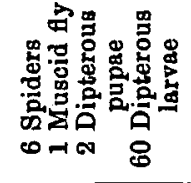 \\
\hline 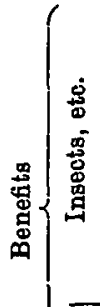 & 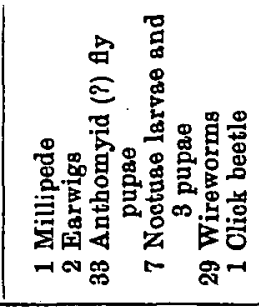 & 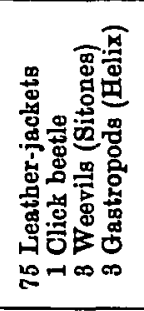 & 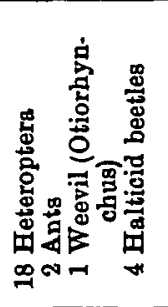 & 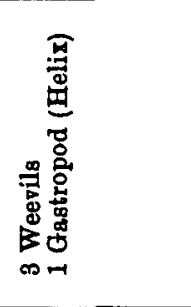 \\
\hline 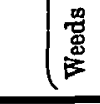 & 1 & 1 & 1 & 1 \\
\hline 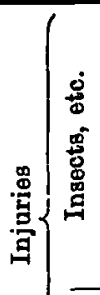 & 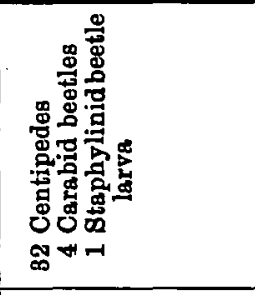 & 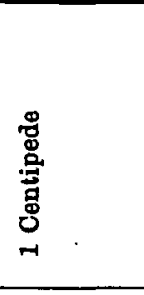 & 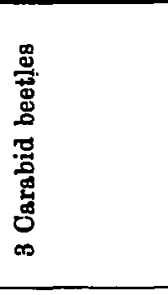 & 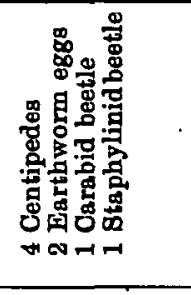 \\
\hline 总 & 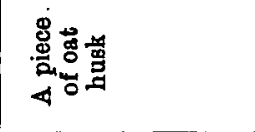 & 1 & 1 & 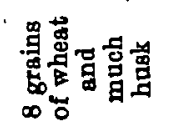 \\
\hline 总 & $\circ$ & $\circ$ & 总 & ot \\
\hline 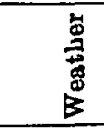 & 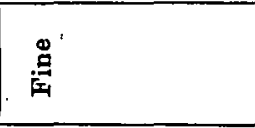 & 몰 & 悬 & 量 \\
\hline 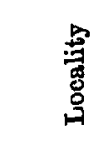 & 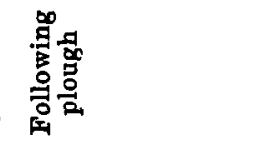 & 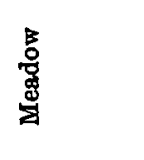 & 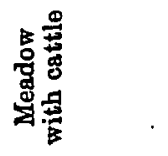 & 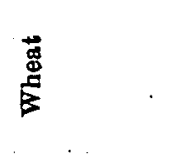 \\
\hline$\frac{\mathscr{D}}{\stackrel{\mathbb{m}}{\mathcal{M}}}$ & 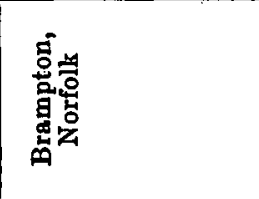 & 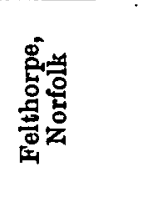 & 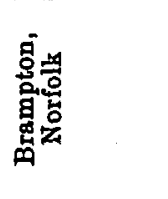 & 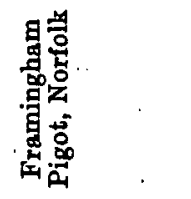 \\
\hline 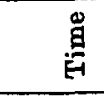 & 吕 & 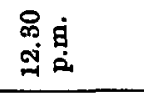 & 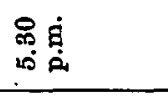 & 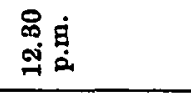 \\
\hline 罯 & 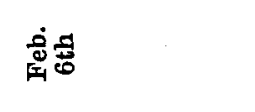 & 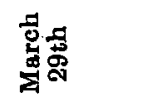 & 害呫 & 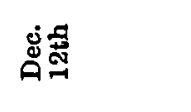 \\
\hline$\dot{\dot{z}}$ & $\infty$ & $\stackrel{\infty}{\infty}$ & ज्ञ & 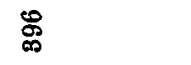 \\
\hline
\end{tabular}




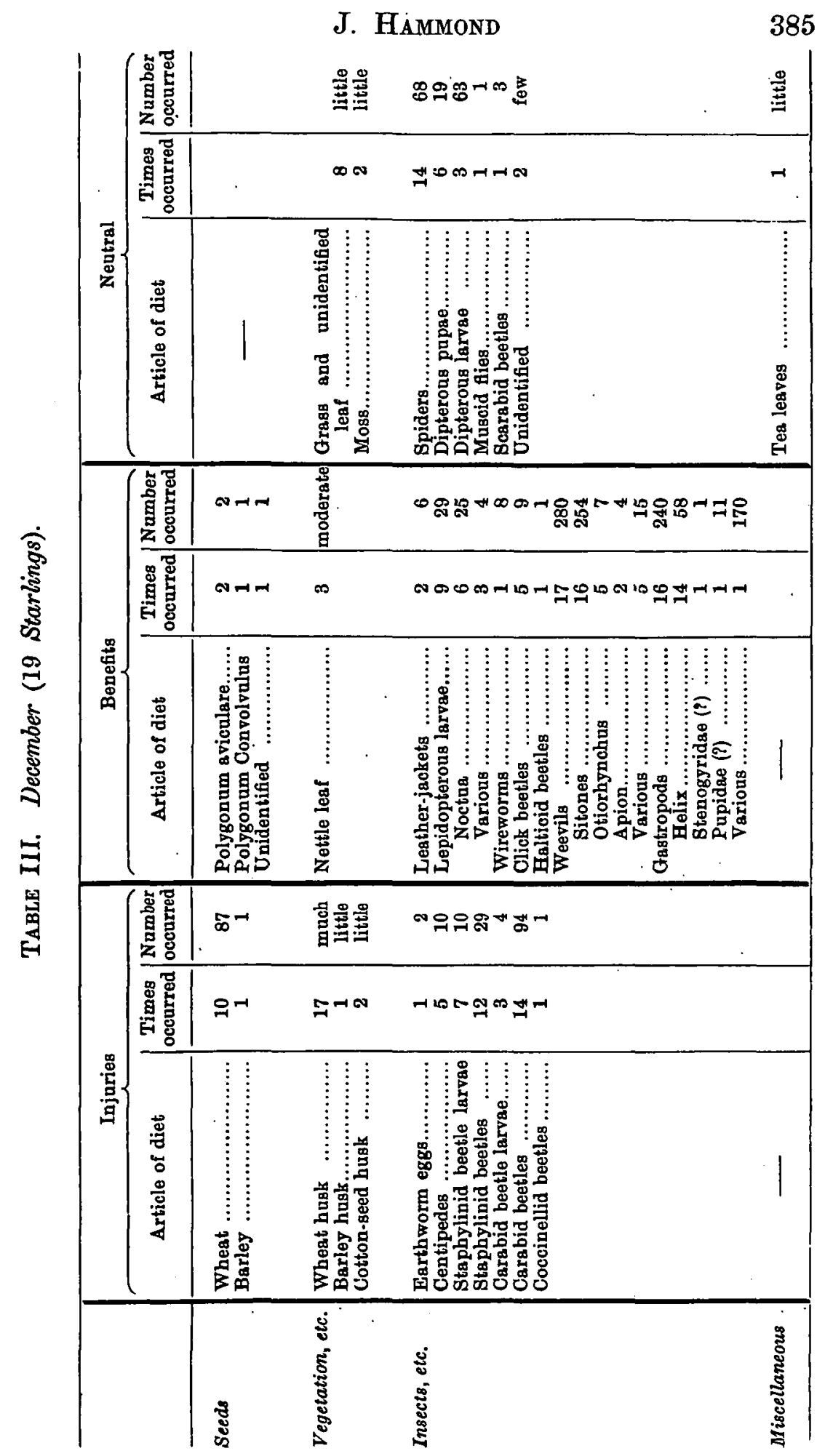




\title{
Investigation concerning the Food of certain Birds
}

\author{
TABLE II.
}

This table shows the way in which the record of the details concerning each bird was kept. The first five columns consist of field notes; while the rest, with the exception of column six, comprise the results of investigating the stomach contents.

\section{TABLE III.}

This table is an example of those which have been compiled in order to analyse the mass of details contained in the record, of which extracts have been given in Table II. The object in view is to present at a glance the food of the bird for any particular month, so that some idea can be formed of its benefits or injuries at that time of year. Such tables and numbers are necessary, for as has been pointed out by Theobald (18), if we rely only on our own judgment, a certain amount of prejudice must come in. The actual figures for each month have not been given, as they are embodied in Table IV, but the most important features are included in the discussion of the monthly results below.

The following is a description of the food taken during each month :-

February.-The bulk of the food consisted of insects, etc., of which the most important were Centipedes, Leather-jackets, Wireworms, Gastropods and Bibio fly larvae. Some grain with a considerable amount of husk was also taken; much of this was undoubtedly from dung, as the general appearance and presence of Mycetophilid fly larvae indicated. Birds which came from sheepfolds, in addition to the common insects, contained pieces of oat grain, cotton seed husk and cut hay, which were probably taken from the feeding troughs. No. 9 [Table II] is an example of the large number of insects, etc., taken when the bird is following the plough.

March.-The food consisted chiefly of insects, etc., of which Staphylinid beetles and their larvae, Curabid beetles, Click beetles, Weevils, Gastropods, Spiders and Mycetophilid fly larvae were present in greatest numbers. The corn husk taken was almost entirely from dung. Weed seeds occurred very occasionally. Tea leaves with odds and ends of rubbish found in several birds indicate their habit of searching in dust heaps. The large number of insects consumed by birds frequenting meadow land will be seen in No. 95 [Table II].

April.-A short spell of cold weather at the beginning of the month 
coincided with the period at which some of the spring sown corn was coming up and as a result mucb grain and husk (both barley and wheat) was taken. At the same time, however, many insects etc. were eaten, the majority being Staphylinid and Carabid beetles, Leather-jackets, Ants, Wireworms, Click beetles, Weevils and Gastropods. On two occasions during the frosty weather pieces of swede bulb were taken.

May.-The food consisted almost entirely of insects, many of which however were beneficial. The food of the young (which is included in this month's results) consisted for the most part of Carabid beetles, Leather-jackets, Click beetles and Weevils.

June.-The bulk of the food consisted of insects, of which the most important were Carabid beetles, Leather-jackets, Ants and their pupae, Click beetles and Weevils. A little grain [Hemp, Canary grass and Oats] occurred; this was probably stolen from pheasants food although presumably there was a plentiful supply of insects.

July.-The food again consisted mostly of insects. Grain [hemp etc.] was taken in small quantities, presumably from pheasants food. Evidence concerning the effect of the bird on, fiuit growing occurred during this month, strawberries being found on three occasions. It was quite a common sight at this time of the year to see flocks of starlings assembling round cattle on the meadows and clover leys; these birds on being examined were found to contain a large number of Heteroptera, Weevils and other insects (No. 247, Table II). It is probable that starlings assemble in these localities for the insects which are disturbed by the treading of the cattle, rather than for the reputed ticks.

August.-Insects, chiefly Carabid beetles, Lepidopterous larvae, Weevils and Dipterous pupae, form the bulk of the diet. Strawberries occurred twice, while towards the end of the month a few elderberries were taken.

September.-The food this month consisted mainly of insects etc. and berries. Among the insects etc., Carabid beetles, Earwigs, Lepidopterous larvae, Weevils and Spiders were those which occurred in largest numbers. The most noteworthy point this month was the attack on elderberries; many of the stomachs and their contents were stained a deep purple. Blackberries were also taken in small quantities. In one case corn (wheat) was taken from the stubbles.

October.-Of the insects which formed the greater portion of the diet Staphylinid beetles, Lepidopterous larvae, Weevils, Dipterous larvae and pupae and Scarabid beetles were the most conspicuous. 


\section{Investigation concerning the Food of certain Birds}

In the beginning of the month elderberries and blackberries were taken and towards the end some corn husk was found.

November.-'This month was marked by the great amount of seed wheat and husk found; $92 \%$ of the birds examined contained this material.

The damage is done just as the blade is appearing through the ground. A hole is dibbled round the blade and the germinating grain pulled out and eaten; as often as not the blade is broken off at the same time, this depending on the age of the plant. On examining the stomach contents of these birds one finds sound grain, that which has just germinated, the empty husks, and usually embryos (scutellum) often with the roots and occasionally the soft part of the blade attached. On no occasion was the foliage of wheat found. At the same time, however, a number of insects etc. were eaten, chiefly Staphylinid beetles and their larvae, Lepidopterous larvae, Weevils, Gastropods, Spiders and Dipterous larvae. In a bird from Hunstanton the remains of a crab were found.

December.-Much seed corn (wheat) and husk were again taken during this month, $89 \%$ of the birds containing this material (No. 396, Table II). It was found that the later sown wheat was damaged most; when it grows beyond a certain stage (probably when all the endosperm bas been used up) the birds do not interfere with it. Many insects etc. were also taken; the most important of these were Carabid beetles, Weevils, Gastropods, Spiders and Dipterous larvae (Table III).

January.-A smaller amount of corn was taken during this month and some of the husk was probably from dung. Insects etc. occurred in large numbers; the most important of these were Staphylinid and Carabid beetles, Ants, Click beetles, Weevils, Gastropods, Spiders and Mycetophilid, Stratiomyid and other Dipterous larvae. An unusual number of weed seeds were present; this was probably due to the frosty weather, which seems to cause a very heterogeneous diet. The occurrence of woodlice is interesting in connection with the observations of Newstead (12) who states that these were picked up but rejected by starlings. It appears from the present investigation that they are only eaten under stress of weather.

\section{TABLE IV.}

This table represents the subject from the point of view of the food article. It shows the time of year when the various food substances 
were eaten and also the quantities in which they were taken. The table is a modified form of that used by Holling (6) for rooks. The monthly results; of which Table III is an example, have been calculated down to a common basis of ten stomachs for the purpose of comparison. The numbers that occurred and not the number of occurrences have been used wherever possible in the calculations, for it was considered that the latter would present a wrong idea of the position occupied by the substance in the bird's diet.

To mention briefly a few of the facts shown by this table:-

Wheat is taken to a large extent in the autumn and in smaller quantities in the spring. Barley and oats occur mainly in the spring.

There is no regularity in the occurrence of weed seeds. Of husk, wheat is the most important and occurs most frequently during the winter and spring months. With regard to insects etc., Centipedes, Staphylinid and Carabid beetle larvae, Millipedes, Wireworms and Click beetles occur frequently during the autumn, winter and spring mouths; but practically none are taken during the summer. This might be accounted for by the fact that ploughing goes on principally during the former period. As the occurrence of many insects is normally limited to certain times of the year (Telephorid beetles, Heteroptera, Bibio flies, etc.), it is only natural that they should be taken by starlings during the periods at which they are most plentiful. The number of Lepidopterous larvae taken rises in August, September and October; it is possible that this may be due to their exposure as a result of the corn harvest. With Weevils, there are periodic rises and falls in the numbers taken; this may possibly in some measure be due to the occurrence of successive broods. Gastropods are taken in larger numbers during the winter months; this perhaps is due to the lack of cover at this time of year. The consumption of spiders appears fairly constant throughout the year, although on the whole tending to rise during the winter months. The occurrence of Mycetophilid fly larvae is almost entirely limited to the winter; Stratiomyid and Dipterous larvae follow almost the same course, while Dipterous pupae and Scarabid beetles are taken mostly in the autumn. The miscellaneous substances. occur haphazard although perhaps slightly more often during the winter months. With regard to the material classed as grass and unidentified leaf, it is thought that its occurrence is accidental in nature, as it was generally found in very small quantities and was often tangled as though it had been wrapped round a Leatherjacket.or picked up with some other object. 


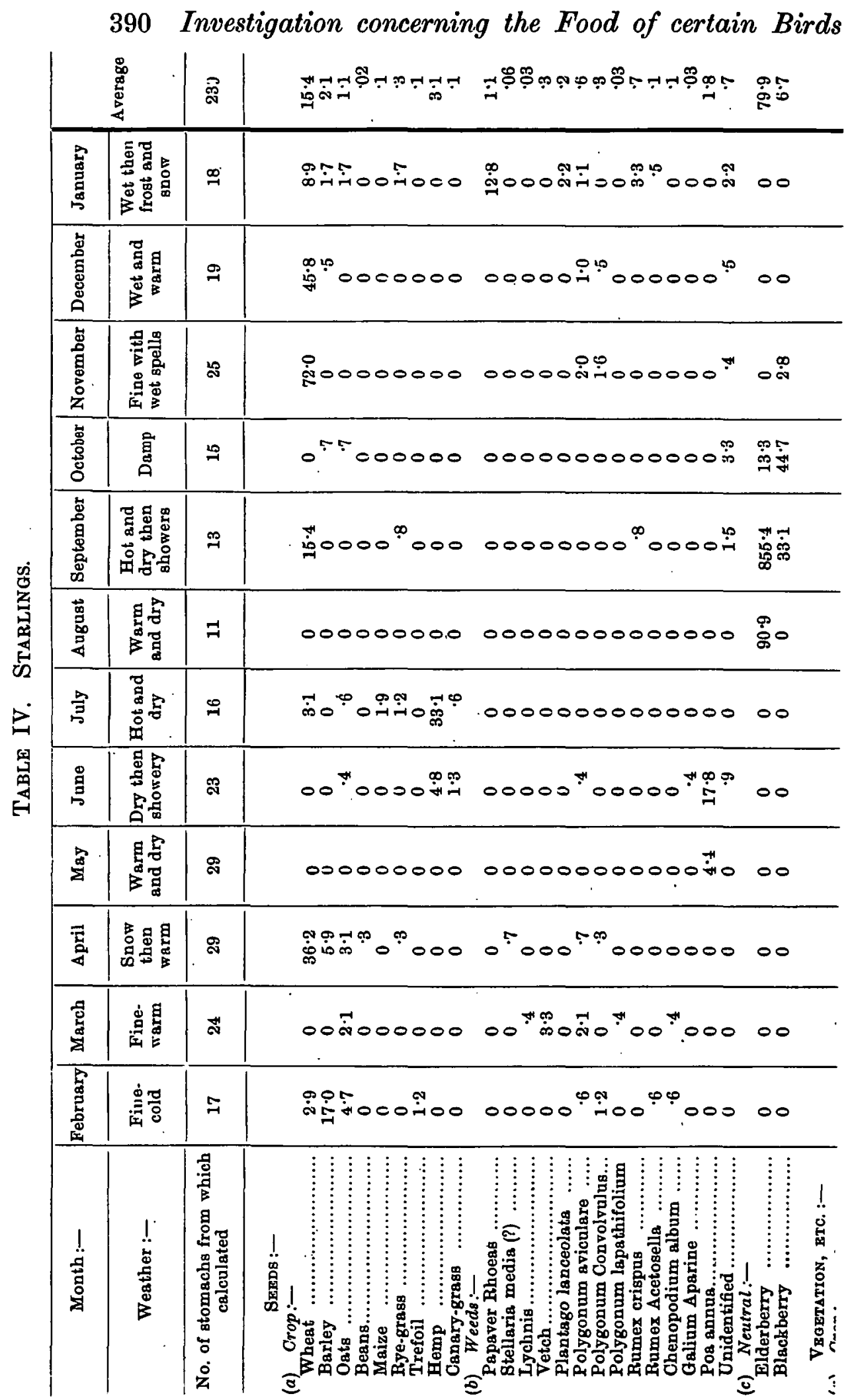




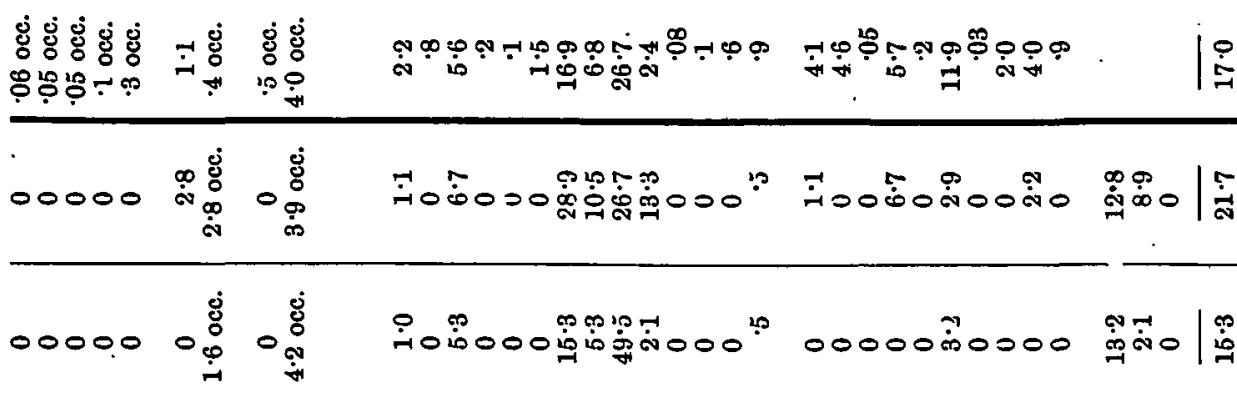

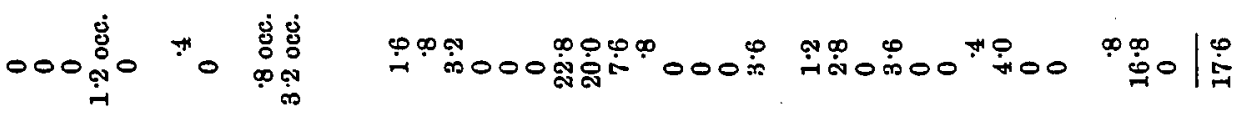

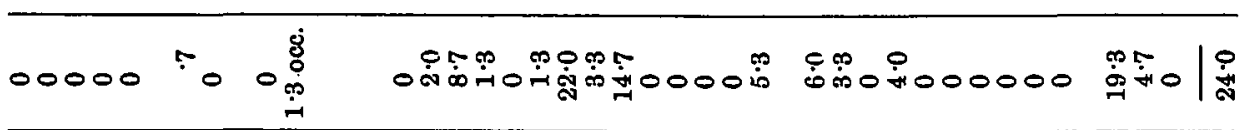

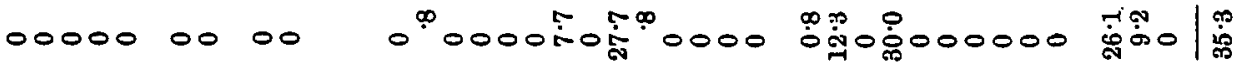

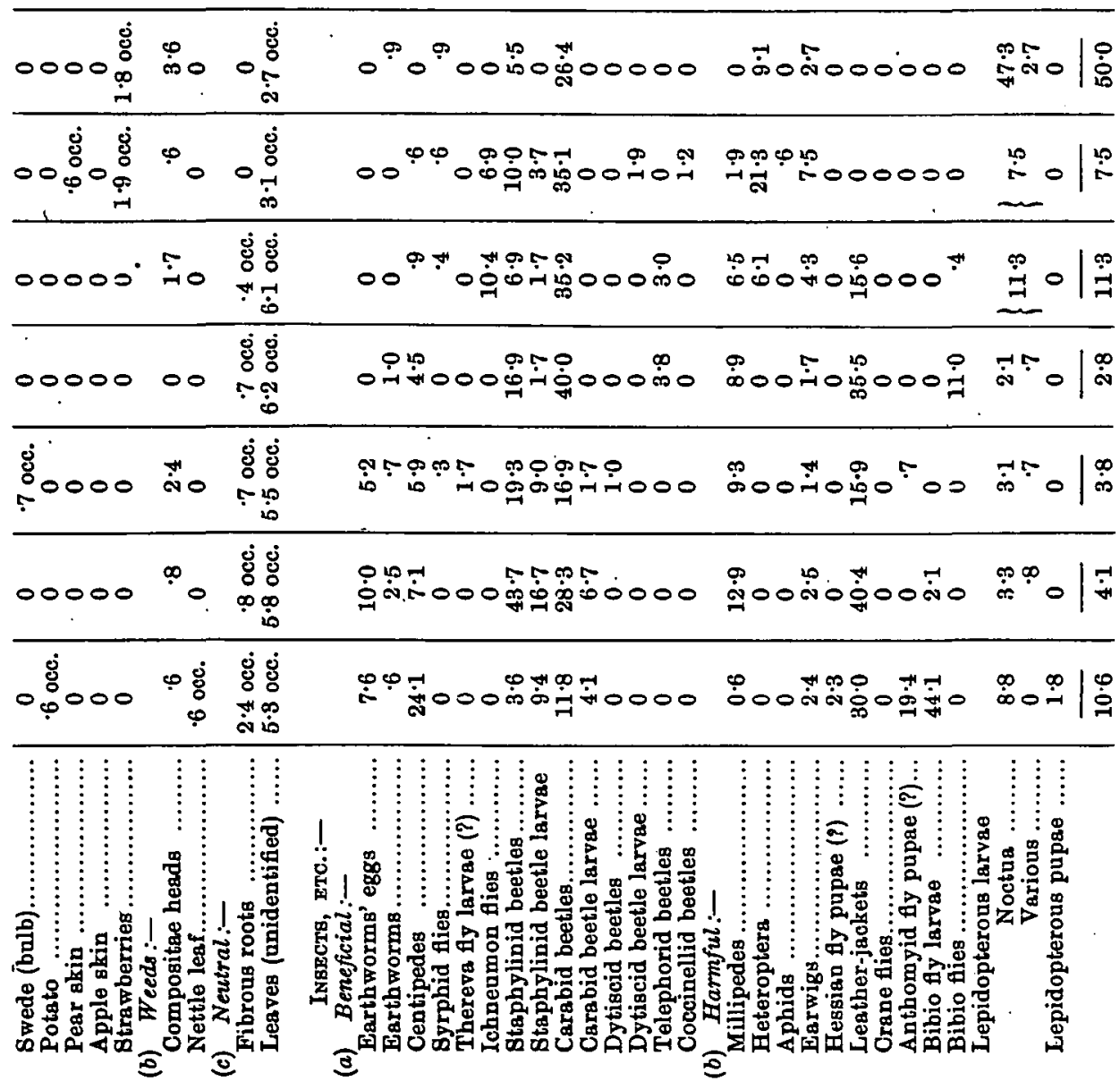


392 Investigation concerning the Food of certain Birds

\begin{tabular}{|c|c|c|c|c|c|}
\hline & 离 & 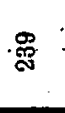 & 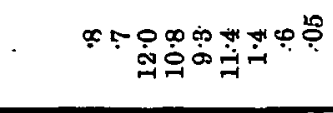 & & $\mid \stackrel{\grave{g}}{q}$ \\
\hline 兽 & 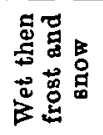 & $\stackrel{\infty}{\sim}$ & . $\quad$ o & 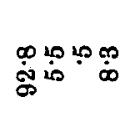 & 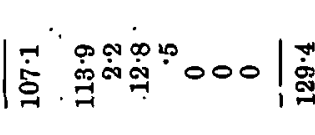 \\
\hline 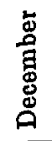 & 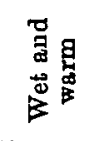 & 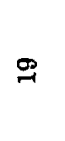 & $0000 \stackrel{4}{4} \operatorname{\psi n}^{\circ} 00$ & 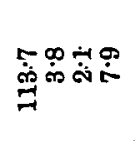 & 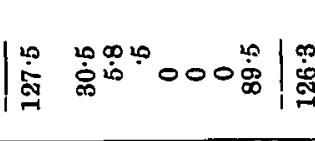 \\
\hline 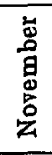 & 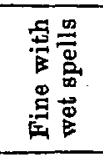 & $\stackrel{10}{\circ}$ & 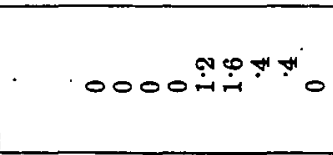 & $\stackrel{\infty}{\dot{D}} \dot{\infty} 0^{\infty}$ & 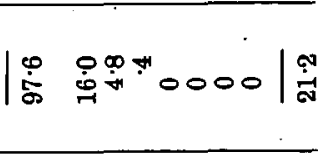 \\
\hline 若 & 煦 & .20 & 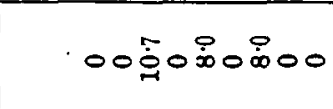 & 赵 & 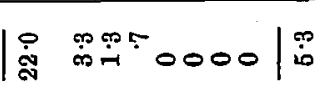 \\
\hline 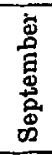 & 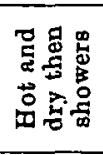 & $m$ & $00 \stackrel{\infty}{\dot{\delta}} 000^{\varphi \infty}$ & 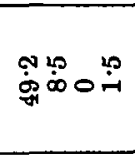 & 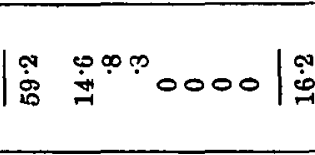 \\
\hline 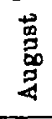 & 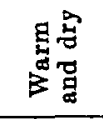 & $\Rightarrow$ & ஸ் & 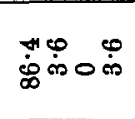 & 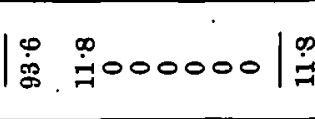 \\
\hline 常 & 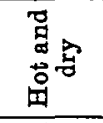 & $\stackrel{\infty}{-\infty}$ & 象品 & 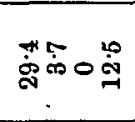 & : \\
\hline 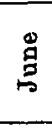 & 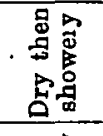 & $\mathscr{A}$ & $\dot{m}_{\rightarrow \rightarrow 00}$ & $\underset{\infty}{\varphi}$ & 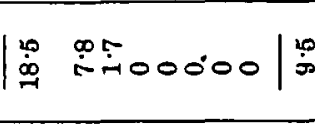 \\
\hline 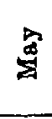 & 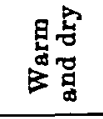 & $\mathscr{乛}$ & 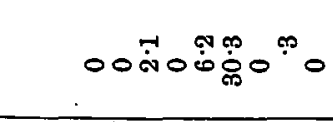 & ڤั) & $\stackrel{\infty}{j}_{i}^{\infty}$ \\
\hline $\overrightarrow{\tilde{E}^{\prime}}$ & 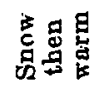 & Д̊ & 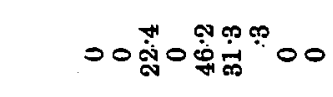 & 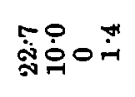 & 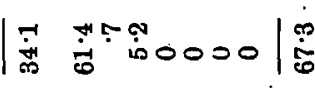 \\
\hline 总 & 㮍罢 & 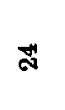 & 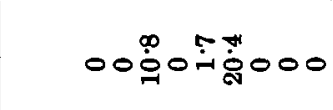 & من & 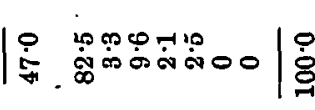 \\
\hline 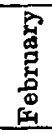 & 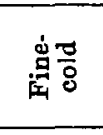 & 5 & $0000 \frac{\pi}{\pi}+\frac{1}{\dot{H}}+00$ & 泀 & 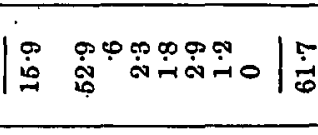 \\
\hline 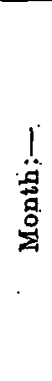 & 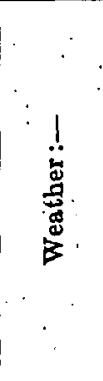 & 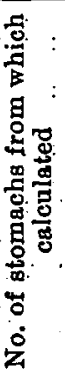 & 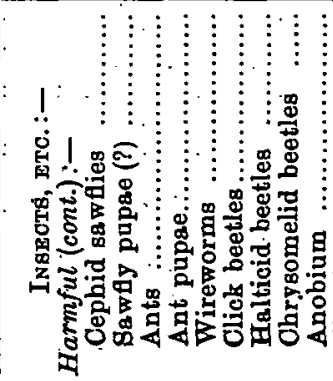 & 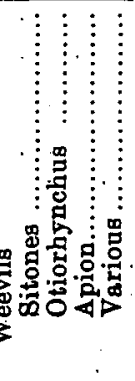 & 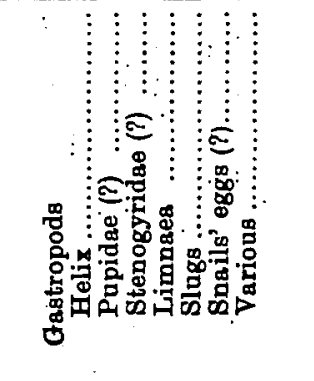 \\
\hline
\end{tabular}




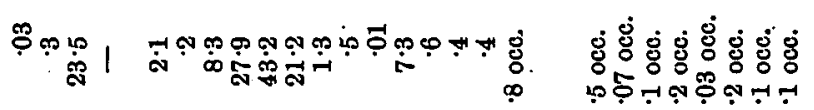

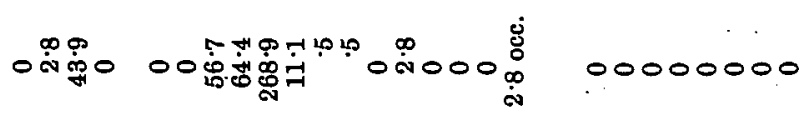

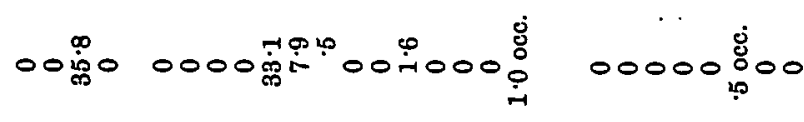

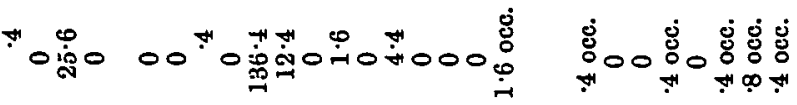

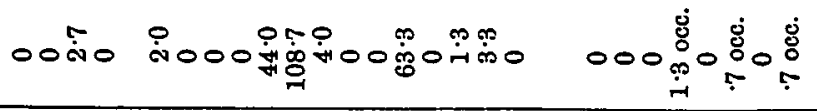

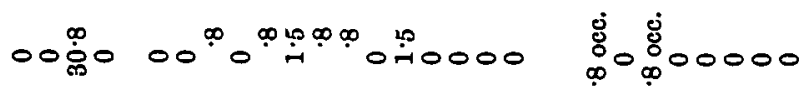

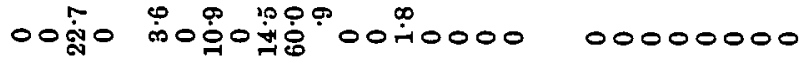

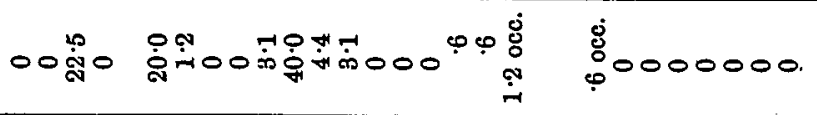

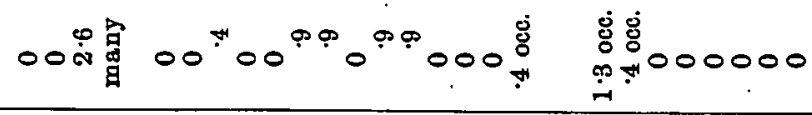

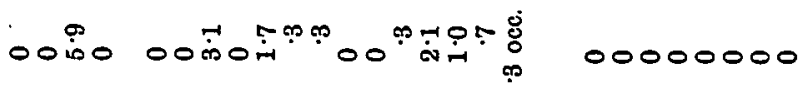

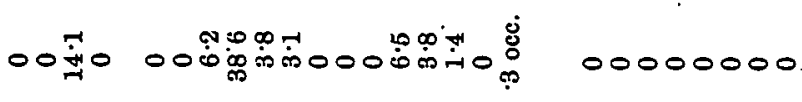

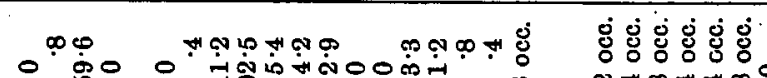

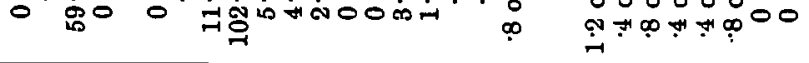

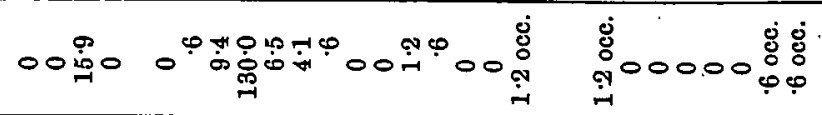
e 


\section{Investigation concerning the Food of certain Birds}

In order to obtain a total estimate of the bird's food, the monthly results have been averaged and placed in a column at the end of Table IV; thus these figures represent the numbers of each article which would be found in ten average stomachs. These numbers may be balanced against one another on some such assumption that 10 grains of wheat $=1$ wireworm, as has been done by Hollrung (6) in the case of the rook. Looked at in this way it seems to be a beneficial bird on the whole; but we have yet to consider the question of migration. It is stated by Saunders (15) that the starling migrates to this country from Northern Europe in the autumn (our birds going further south and west) and returns in the spring. One definite case was noted in the course of this investigation; a bird was killed near Thetford, Norfolk, which had been ringed a few days before in Viborg, Denmark, by $C$. Mortensen who is investigating migration. It is the autumn. migrants from abroad which do the damage to seed corn, but at the same time it ought to be pointed out that they are eating considerable numbers of insects, etc. To abate this plague there seem to be two courses open (since the birds are very difficult to scare off the fields), either (i) to dress the seed corn with something that will render it distasteful to birds, or (ii) as an extreme measure if (i) fails, to kill off the autumn migrants in large numbers.

With reference to (i) experiments undertaken by the German Imperial Biological Institute (22) have shown that corn dressed with Prussian blue, creolin or powdered aloes was rendered distasteful to rooks. Numerous tar preparations have been put forward, but they seem open to the objection that they retard germination, altbough a dressing mentioned by Sawyer (16) is supposed not to have this effect.

With regard to (ii) it is a matter of general belief and has been recorded by Saunders (15), Hooper (7) and Collinge (3) that starlings have increased enormously in numbers of late years. It has been suggested that this is due to a series of mild winters, but it may possibly be a result of their preservation in those places from which they migrate (21).

It is probable that this increase in numbers has been out of proportion to that of their insect food, so that wheat has been taken in order to eke out the diet. It should then follow that if their numbers were reduced, insect food would be in sufficient abundance to form the entire diet without the addition of grain. Perhaps the easiest way to reduce their numbers would be by the use of poison; this course seems open to the objection that the poison might be misused, but this ought not to occur if under proper control. 


\section{Conclusions.}

(1) The starling is very beneficial during the late spring, summer and early autumn months, eating many harmful insects although a number of beneficial ones are also destroyed.

(2) During the autumn, and to a less extent in the spring, much harm is done by the consumption of seed corn (particularly wheat); many harmful insects however are also destroyed during this period.

(3) Owing to the fact of the bird's autumn and spring migrations, the remedies suggested are, either (i) to dress the seed corn with something which renders it distasteful to birds; or (ii), if suggestion (i) cannot be carried out successfully, to kill off the autumn migrants in large numbers.

\section{Part III. The Lark.}

This bird was considered a suitable subject for investigation, as, on the one hand, most of the standard books on birds regard it as beneficial to agriculture; whereas, on the other hand, Hooper (7) states that it is destructive to wheat, vetches, cabbages, etc., and farmers have complained of the damage to clover leys and seed wheat. The only records of its stomach contents that could be found were those published by Newstead (12).

\section{TABLE I. LARKS.}

Number and localities of birds examined each month.

\begin{tabular}{|c|c|c|c|c|c|c|c|c|c|c|c|c|c|}
\hline Locality & 通 & $\begin{array}{l}\text { 总 } \\
\text { 营 }\end{array}$ & 蛋 & 焉 & 䓀 & $\stackrel{3}{3}$ & 安 & $\begin{array}{l}\text { 芯 } \\
\text { 心 }\end{array}$ & $\dot{8}$ & 宽 & 官 & 离 & 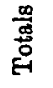 \\
\hline 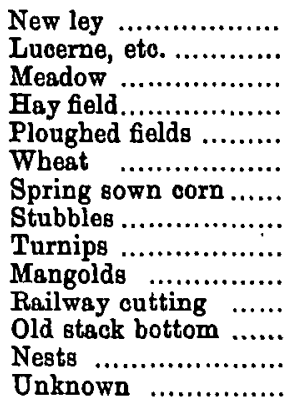 & $\begin{array}{r}10 \\
2 \\
0 \\
0 \\
1 \\
2 \\
1 \\
2 \\
0 \\
0 \\
0 \\
0 \\
0 \\
0\end{array}$ & $\begin{array}{l}7 \\
1 \\
4 \\
0 \\
4 \\
7 \\
4 \\
0 \\
0 \\
0 \\
0 \\
0 \\
0 \\
0\end{array}$ & $\begin{array}{l}4 \\
1 \\
0 \\
0 \\
1 \\
7 \\
3 \\
0 \\
0 \\
0 \\
0 \\
0 \\
0 \\
0\end{array}$ & $\begin{array}{l}9 \\
0 \\
0 \\
0 \\
1 \\
1 \\
8 \\
0 \\
1 \\
0 \\
0 \\
0 \\
0 \\
0\end{array}$ & $\begin{array}{l}0 \\
0 \\
1 \\
1 \\
0 \\
0 \\
1 \\
0 \\
0 \\
6 \\
1 \\
0 \\
3 \\
0\end{array}$ & $\begin{array}{l}0 \\
0 \\
1 \\
2 \\
0 \\
0 \\
1 \\
0 \\
4 \\
4 \\
0 \\
1 \\
0 \\
0\end{array}$ & $\begin{array}{l}0 \\
0 \\
0 \\
1 \\
0 \\
0 \\
0 \\
7 \\
0 \\
0 \\
0 \\
0 \\
0 \\
2\end{array}$ & $\begin{array}{l}0 \\
0 \\
0 \\
0 \\
0 \\
0 \\
0 \\
2 \\
4 \\
0 \\
0 \\
0 \\
0 \\
0\end{array}$ & $\begin{array}{l}0 \\
0 \\
0 \\
0 \\
0 \\
1 \\
0 \\
2 \\
1 \\
3 \\
0 \\
0 \\
0 \\
0\end{array}$ & $\begin{array}{l}0 \\
0 \\
0 \\
0 \\
1 \\
8 \\
0 \\
1 \\
3 \\
0 \\
0 \\
0 \\
0 \\
0\end{array}$ & $\begin{array}{l}6 \\
0 \\
1 \\
0 \\
1 \\
5 \\
0 \\
0 \\
0 \\
0 \\
0 \\
0 \\
0 \\
0\end{array}$ & $\begin{array}{r}10 \\
0 \\
0 \\
0 \\
0 \\
2 \\
0 \\
0 \\
2 \\
0 \\
0 \\
0 \\
0 \\
1\end{array}$ & $\begin{array}{r}46 \\
4 \\
7 \\
4 \\
9 \\
33 \\
18 \\
14 \\
15 \\
13 \\
1 \\
1 \\
3 \\
3\end{array}$ \\
\hline Totals............... & 18 & 27 & 16 & 20 & 13 & 13 & 10 & 6 & 7 & 13 & 13 & 15 & 171 \\
\hline
\end{tabular}


396 Investigation concerning the Food of certain Birds

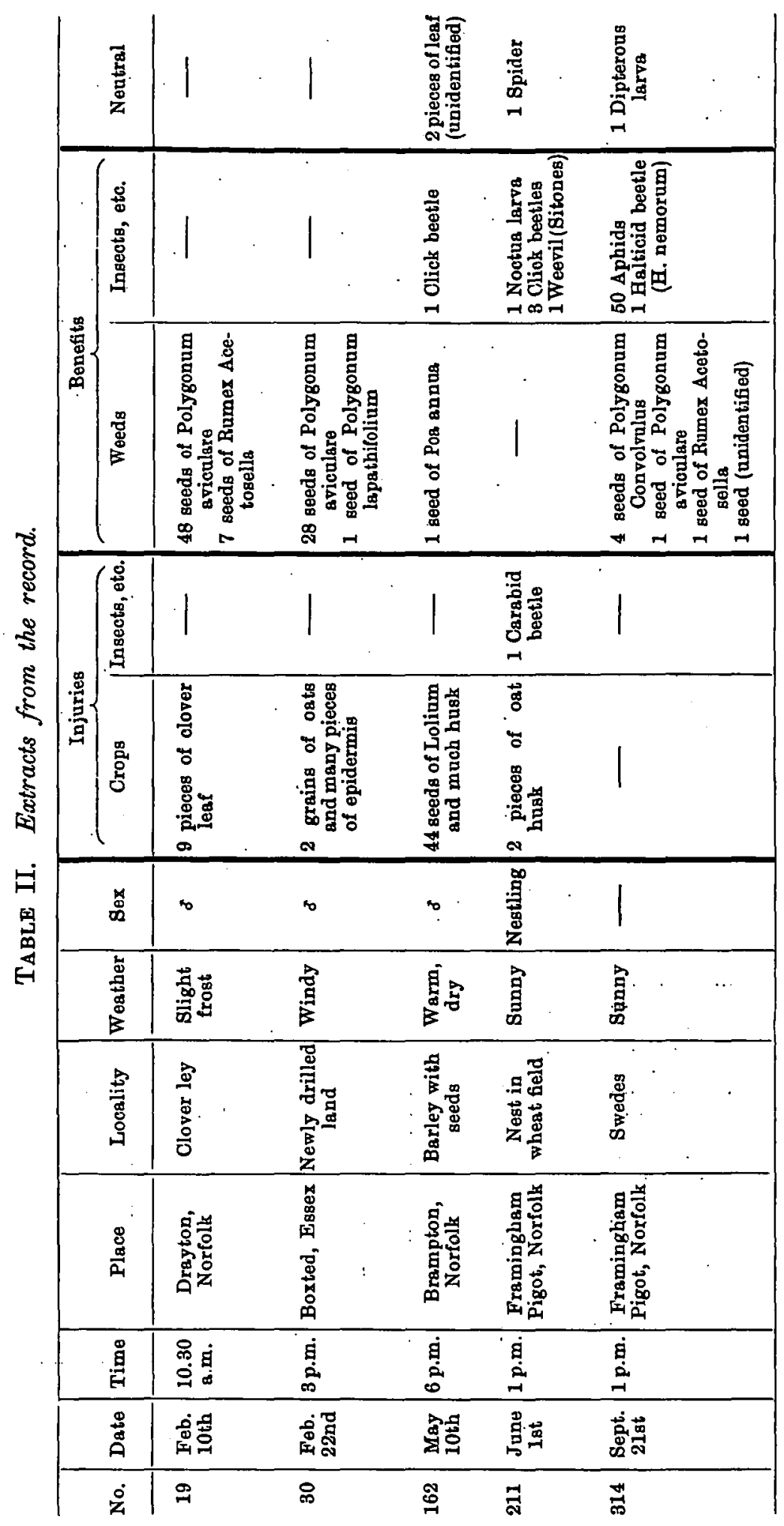




\section{TABLE $I$.}

This table shows the localities from which the birds were taken.

The small numbers examined in September and October indicate the great difficulty in obtaining birds during these months. This was probably due to a period of time elapsing between the dates at which our birds start southward and the foreign migrants arrive.

\section{Table II.}

This table consists of a few extracts from the record of the details concerning each bird. The arrangement is similar to that of the corresponding table for starlings.

\section{TABLE III.}

This table is an example of those which were made to show the monthly food. It was compiled in the same way as in the case of the starling. The results for each month are not given as they are embodied in Table IV. A discussion of the monthly results follows below.

The following is a description of the food taken each month :-

February-During this month $78 \%$ of the birds examined contained the leaves of some crop. The green parts of the leaf were eaten, and mostly, although not always, the smaller leaves were found; as far as could be seen the young shoots and stems were not taken (No. 19, Table II). Weed seeds formed the bulk of the diet and an insect was rarely taken.

March.-Weed seeds, of which Polygonum aviculare is by far the most important, formed the bulk of the diet. Corn in small quantities was taken from the spring sowings (No. 30, Table II), and, as none had germinated, it was concluded that it was taken soon after sowing and had not been properly buried. Crop leaves (wheat, clover and ryegrass) occurred in smaller quantities than in the preceding month. The insects eaten increased in numbers, of these Weevils were the most important.

April.-The greater part of the food consisted of weed seeds; Polygonum aviculare, Polygonum Convolvulus, Stellaria media and Poa annua were present in largest numbers. A little seed corn (barley) was also taken. Insects occurred in about the same numbers as during the previous month.

May.-Insects, mainly Lepidopterous larvae, Click beetles and Weevils, were taken in increasing numbers. The basis of the diet consisted of weed seeds; the most important of these were Poa annua, Polygonum aviculare and Stellaria media. Some of the birds, killed 
398 Investigation concerning the Food of certain Birds

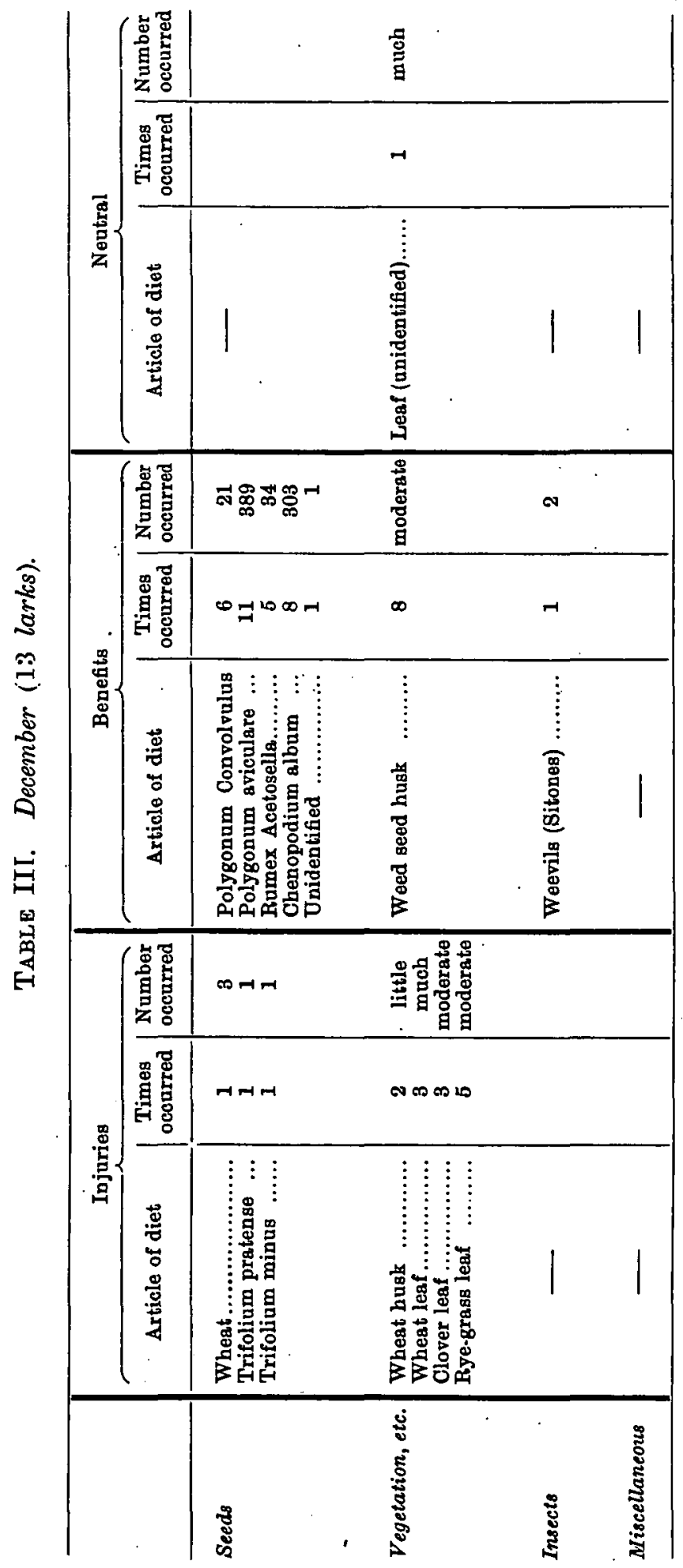


on spring sown corn, contained "small seeds" both clover and rye-grass (No. 162, Table II). In view of the numbers eaten it appears that larks are doing much damage in these localities.

June.-The diet consisted for the most part of weed seeds and injurious insects. The food of the young was almost entirely of insects (No. 211, Table II); this was particularly evident, as the old birds nearly always contained weed seeds. It is interesting to note that the turnip flea beetle (Haltica nemorum) was taken in numbers on several occasions by birds frequenting root fields.

July.-The food again consisted for the most part of weed seeds and injurious insects. Of the former Papaver Rhoeas and Polygonum aviculare were the most important, while of the latter Aphids, Pegomyia betae larvae and Weevils occurred in greatest numbers. In conjunction with the Pegomyia larvae mangold leaf was often taken.

A ugust.-Weed seeds occurred in large numbers, the most important being Papaver Rhoeas and Polygonum aviculare. Insects occurred in smaller numbers, Halticid beetles being most plentiful.

Much corn (wheat, barley and oats) was taken from the stubbles after harvest.

September.-The food consisted almost entirely of weed seeds and Aphids. The latter, owing to the dry season, existed in large numbers on the swedes and had been eaten by birds which were killed in these localities (No. 314, Table II). Of the weed seeds Polygonum aviculare and Lychnis (?) occurred in large numbers. Some corn was also taken from the stubbles.

October.-Weed seeds formed the bulk of the diet; those occurring in greatest numbers were Papaver Rhoeas and Polygonum aviculare. Insects formed the remainder of the diet; of these Weevils and Dipterous pupae were the most important.

November-Polygonum aviculare, Polygonum Convolvulus and Chenopodium album were the most important weed seeds occurring this month. These with a few grains of wheat from the autumn sowings and an occasional Dipterous pupa made up the diet. A number of clover seeds were found in birds which were killed on wheat, an adjoining field having been patched in the autumn with clover.

December. $-69 \%$ of the birds examined this month contained the leaves of some crop. The bulk of the diet consisted of weed seeds, chiety Polygonum aviculare and Chenopodium album. On one occasion wheat was taken from the autumn sowings. The only insects that occurred were two Weevils (Table III). 


\section{Investigation concerning the Food of certain Birds}

\begin{tabular}{|c|c|c|c|c|}
\hline & 这 & $E$ & 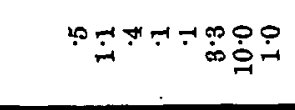 & 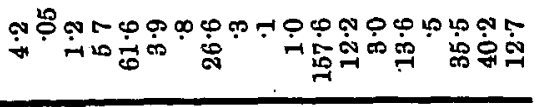 \\
\hline 莺 & 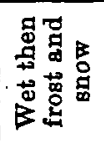 & $\stackrel{9}{\rightarrow}$ & $000 \stackrel{\infty}{-1} 0000$ & 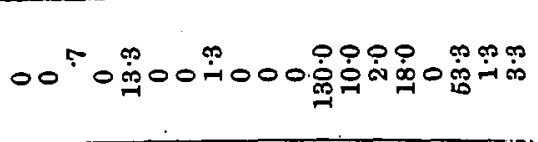 \\
\hline 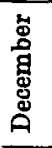 & 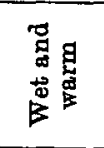 & $\stackrel{\oplus}{\rightarrow}$ & $\dot{n} 0000 \stackrel{\leftrightarrow}{\dot{1}} 00$ & 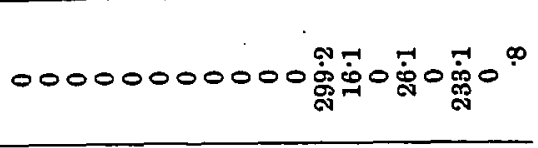 \\
\hline 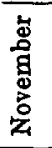 & 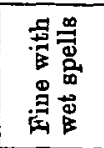 & $\stackrel{\oplus}{\rightarrow}$ & $\dot{\sim} 0000 \stackrel{\text { in}}{0}$ & 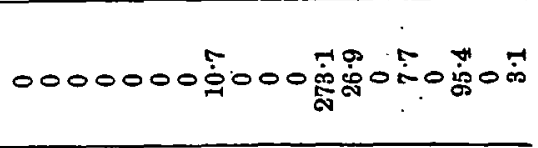 \\
\hline 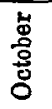 & . 宙 & - & $0000 \ddot{10000}$ & 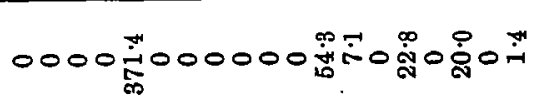 \\
\hline 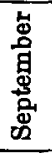 & 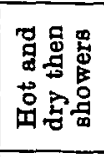 & $\infty$ & 0 in 000000 & 00000 象0气 \\
\hline 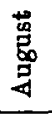 & 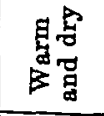 & 우 & 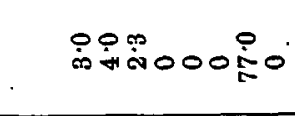 & 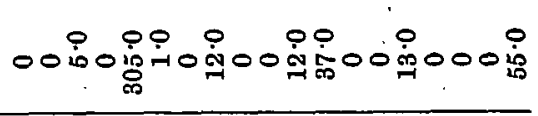 \\
\hline$\stackrel{ }{5}$ & 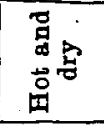 & $\stackrel{D}{\longrightarrow}$ & 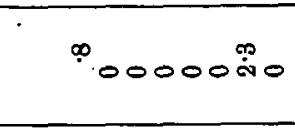 & 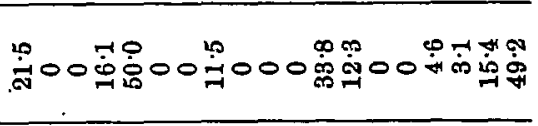 \\
\hline 苛 & 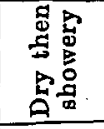 & $\stackrel{20}{\sim}$ & $\stackrel{\infty}{\infty} 00000 \stackrel{\leftrightarrow}{\mathbb{G}}$ & 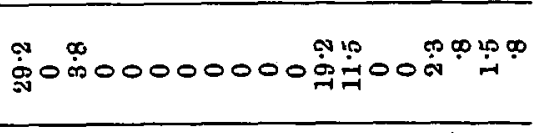 \\
\hline 密 & 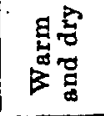 & 오 & o & 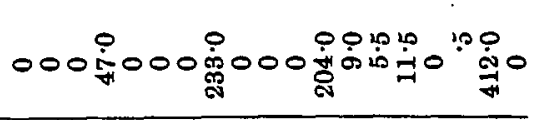 \\
\hline $\overrightarrow{\mathrm{a}}$ & 量最最 & $\mathscr{1}$ & $0 \stackrel{9}{-1} 000000$ & 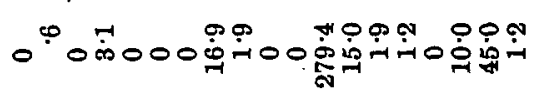 \\
\hline 总 & 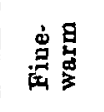 & ล & "ro & 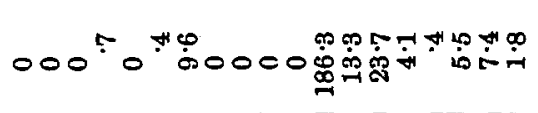 \\
\hline 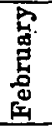 & $\underset{\dot{q}}{\dot{q}}$ & $\stackrel{\infty}{\sim}$ & - $0 \stackrel{4000}{4}$ & 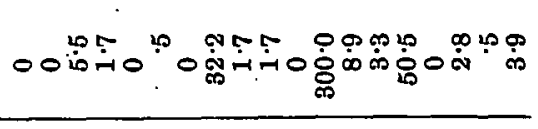 \\
\hline 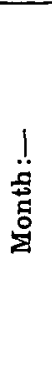 & 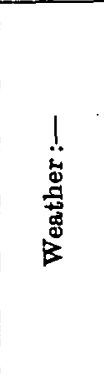 & 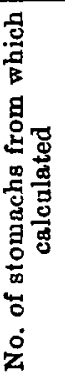 & 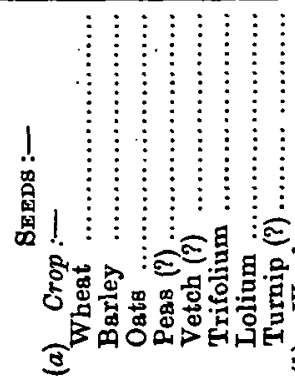 & 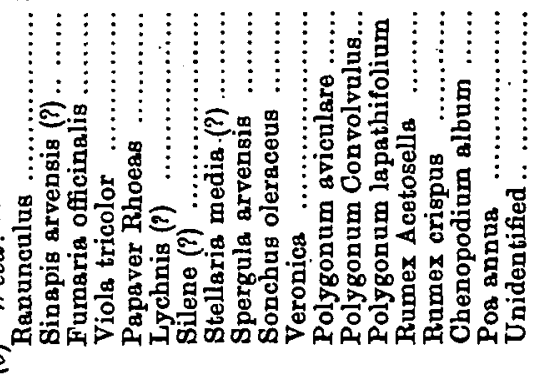 \\
\hline
\end{tabular}




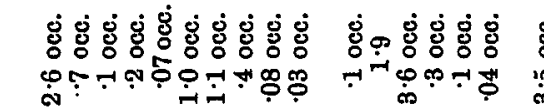

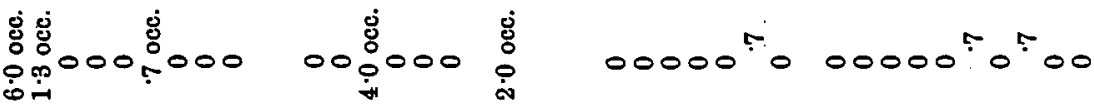

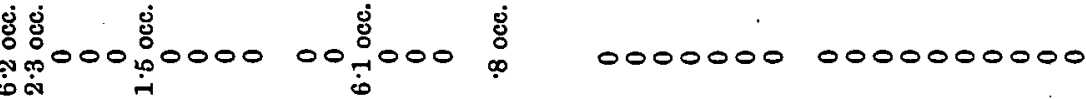

乡்

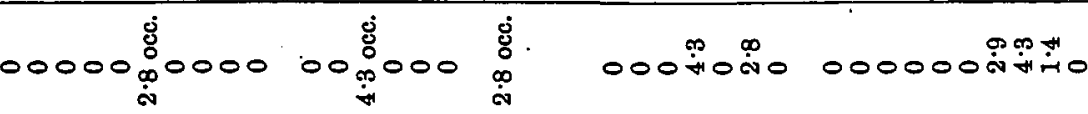

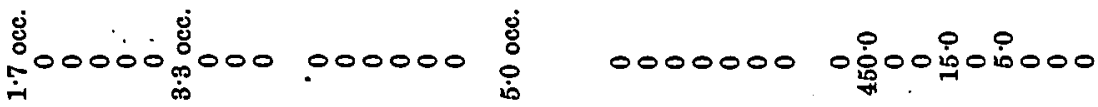

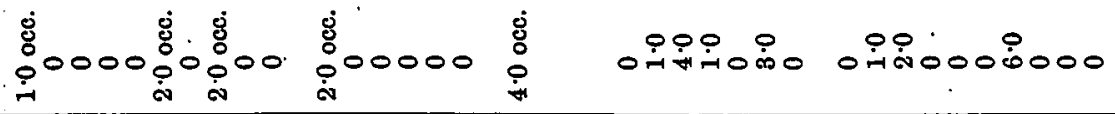

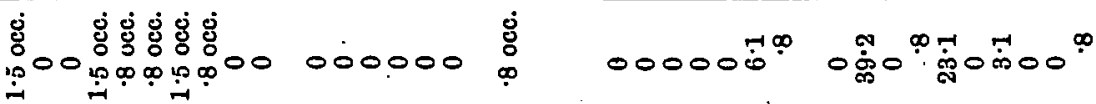

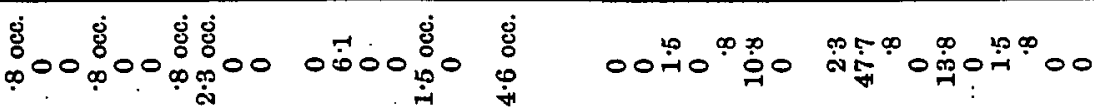
岁

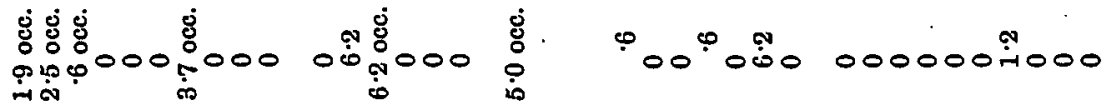

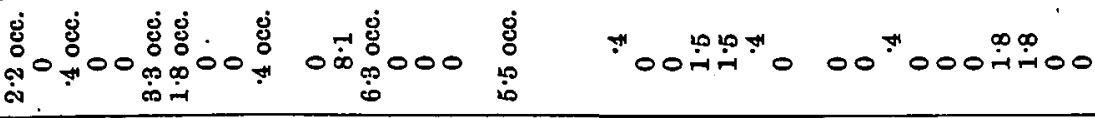

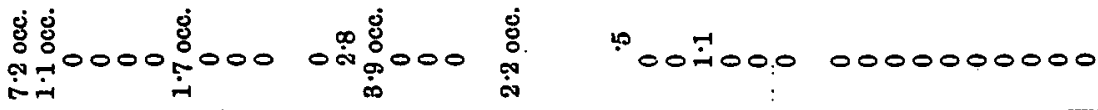

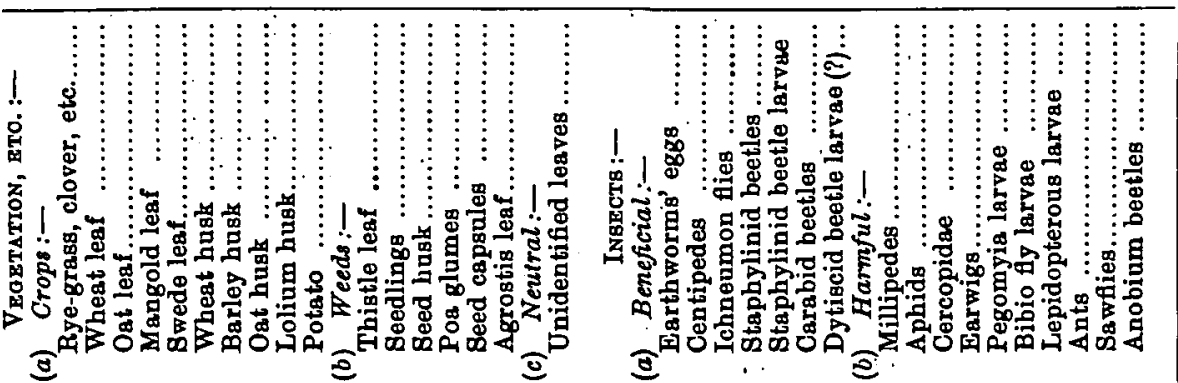


402 Investigation concerning the Food of certain Birds

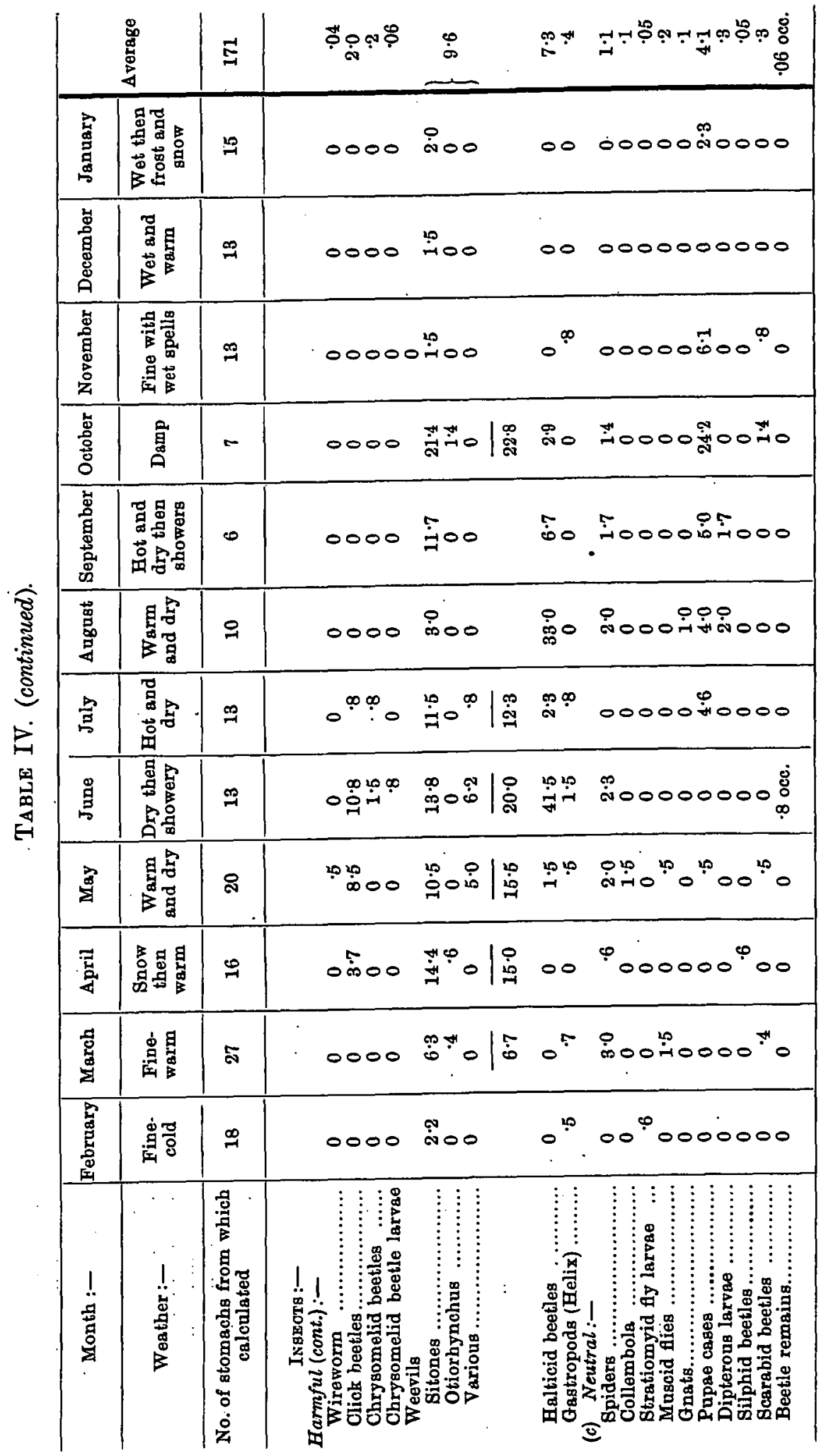


Janutry.-The food consisted mainly of weed seeds; those which occurred in largest numbers were Polygonum aviculare, Chenopodium album and Rumex Acetosella. $73 \%$ of the birds examined contained the leaves of some crop. Extremely few insects occurred.

\section{TABIE IV.}

This table is a comparison of the monthly food in detail, being compiled in the same way as in the case of the starling.

To mention briefly a few of the facts shown by this table:-

Corn is taken at the times of seeding, but not in sufficient quantities to be of importance; much is however taken from the stubbles after harvest, but this is not of much economic value. The number of clover and rye-grass seeds taken in the spring and autumn indicates an injury to this crop. With regard to weed seeds, it will be noticed that only a small number of species occur with any regularity; thus indicating that the lark exercises a special preference for some kinds. Its fondness for seeds of the Polygonaceae is particularly evident. Some species of seeds are taken only at certain times of the year, for example, Poa annua, Polygonum lapathifolium and Papaver Rhoeas. The weed seed figures for June are rather low on account of the inclusion of a number of young birds. The consumption of crop leaves is for the most part confined to the winter months.

Very few beneficial insects are taken, Carabid beetles alone occur with any regularity. Of the harmful insects Aphids, Pegomyia larvae and Halticid beetles occur only in the summer, Click beetles only in the spring, while Weevils are taken regularly, although more occur in the summer months.

Although not shown in the table, the amount of grit found in the gizzards also varied with the time of year, more being present in the winter than in the summer months.

By looking at the last column in Table IV it will be seen that weed seeds are far and away the most important article of diet, harmful insects come next, with crop leaves and "small seeds" forming a small pruportion.

The food of the lark may be summed up as follows:-The bulk of the food consists of weed seeds; this is eked out in the summer months by insects, and in the winter by pieces of leaf, for the most part of crops.

Both Saunders (15) and Newton (13) state that there is a migration of larks to this country in the autumn from Northern Europe and a return in the spring. From this it would follow that the damage to 
404 Investigation concerning the Food of certain Birds

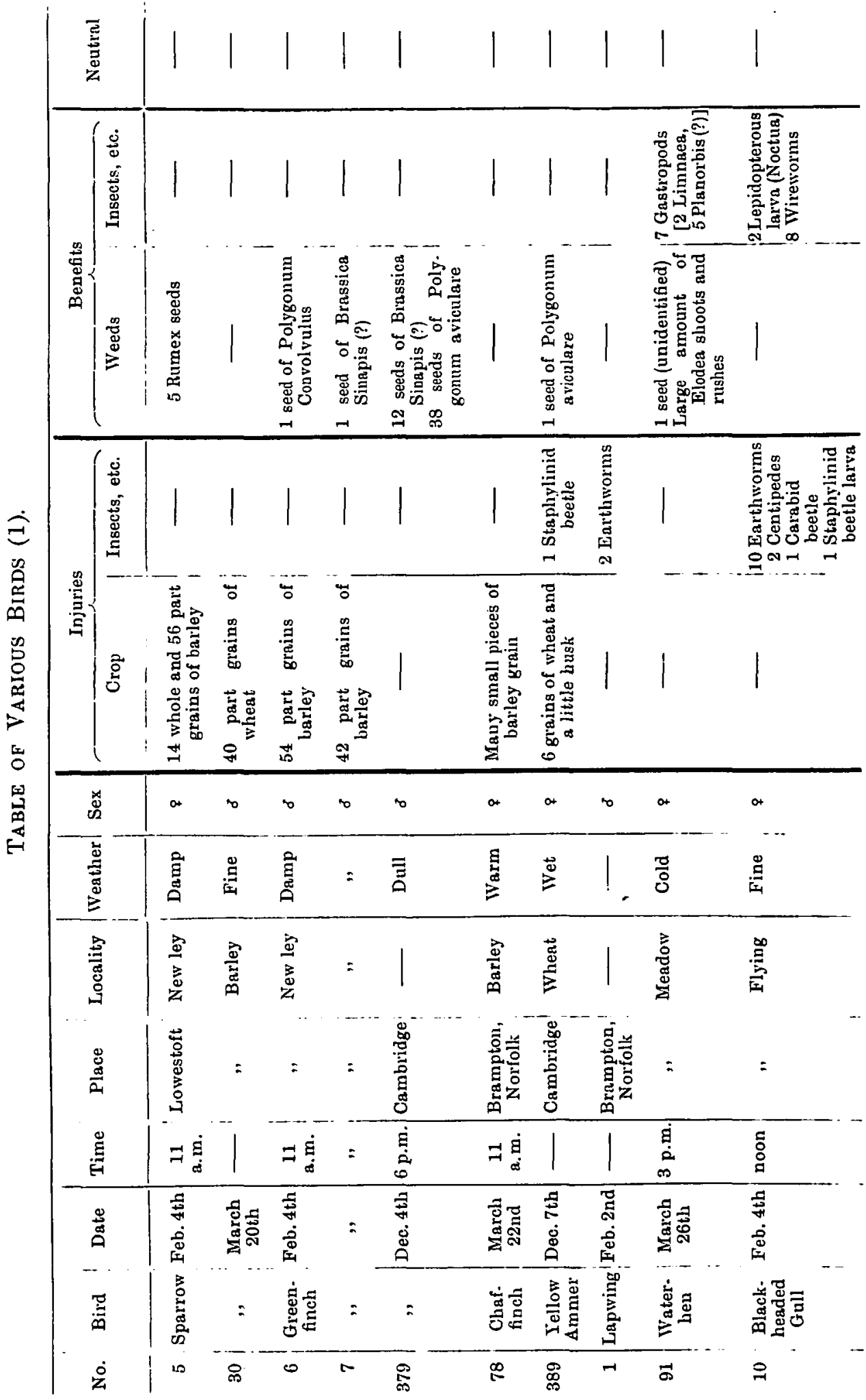




\title{
THE CAMBRIDGE FARM INSTITUTE SERIES
}

Generai. Editors:

\author{
Professor T. B. WOOD and Dr E. J. Russell.
}

In order to meet the needs of the many Farm Institutes already in existence or about to be formed, the Cambridge University Press has decided to issue a series of text books to be called the Farm Institute Series.

The books will be specially written to suit the educational conditions of the Institutes. They are intended for the average student whose object is to farm, rather than for the exceptional man who wishes to make for himself a career as an agricultural expert.

Every endeavour will be made to attain a high standard educationally, by training students to observe, to think, to take an intelligent interest in their daily work and, above all, to appreciate the beauty and wonder of the cominon objects among which their life will be passed. But care will be taken that, in striving after high educational ideals, the fact that farm students must earn their living on the land is not lost sight of. The books will not only provide an interesting account of general principles: the principles themselves will be driven home by many concrete examples taken from the best agricultural practice, and likely to bear directly on the daily work of the farm.

The student's thoughts will be exercised in a very practical manner if he is trained to think in terms of the details of farm practice which will crop up daily when he goes out into the world, and which will largely determine his success or failure.

The books will contain about 150 to 200 pages each ( 35 to 40 thousand words). They will be well illustrated, and the price will be $2 s$. or $2 s$. $6 d$. according to size.

The following volumes have been arranged, the first of which it is hoped to publish in the spring of 1913:

The Feeding of Farm Animals. By Professor T. B. Wood, M.A.

A Student's Book about Soils and Fertilizers. By E. J. Russeld, D.Sc.

Plant Life in Farm and Garden. By Professor R. H. BIFFEN, M.A.

Farm Accounts. By C. S. Orwin.

\author{
CAMBRIDGE UNIVERSITY PRESS \\ ILondoll: FETTER LANE, E.C. \\ C. F. Clay, Manager
}

(Eoinburgh): 100, Princes Street 
J. Hammond

405 .

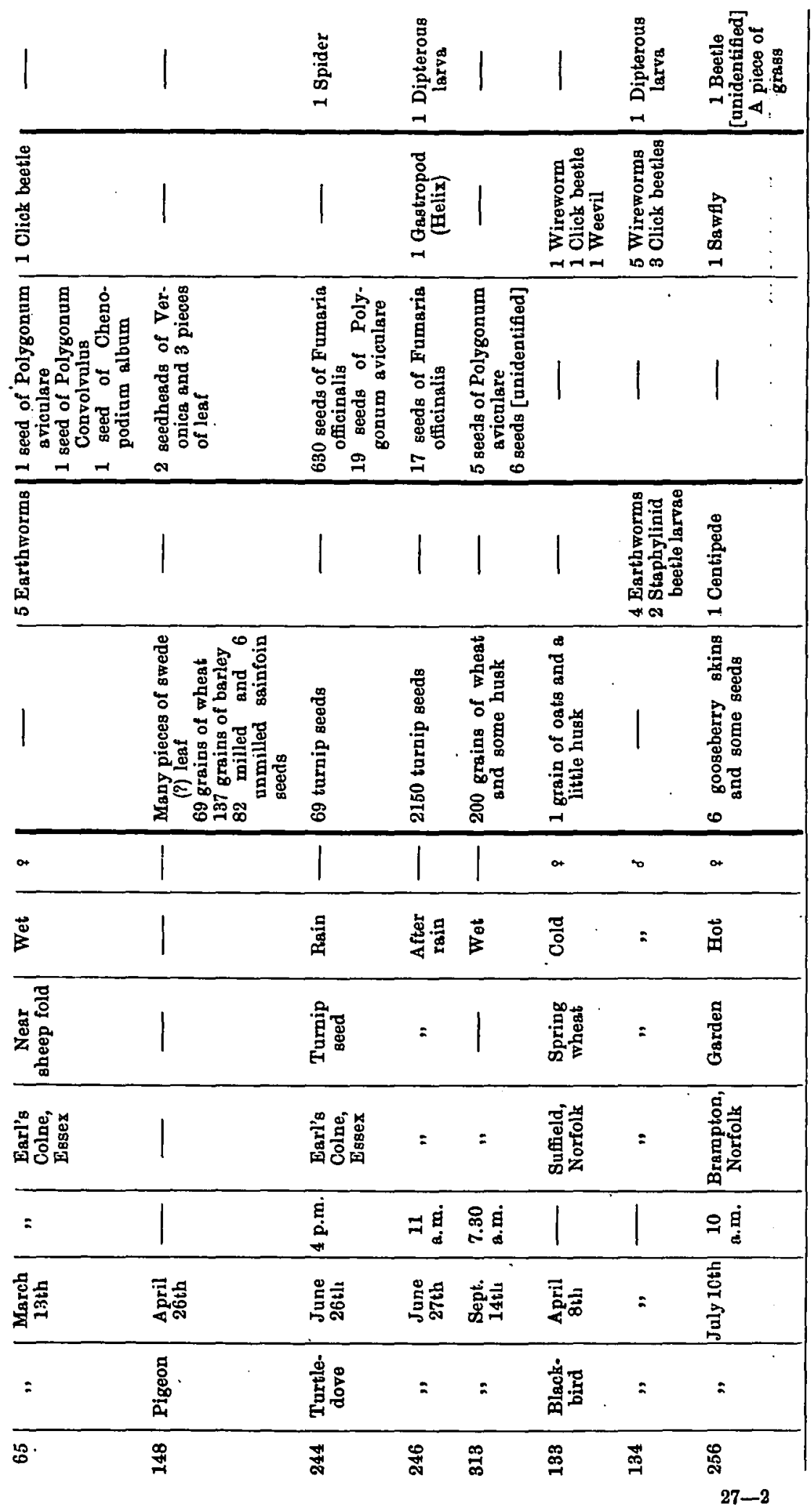


406 Investigation concerning the Food of certain Birds

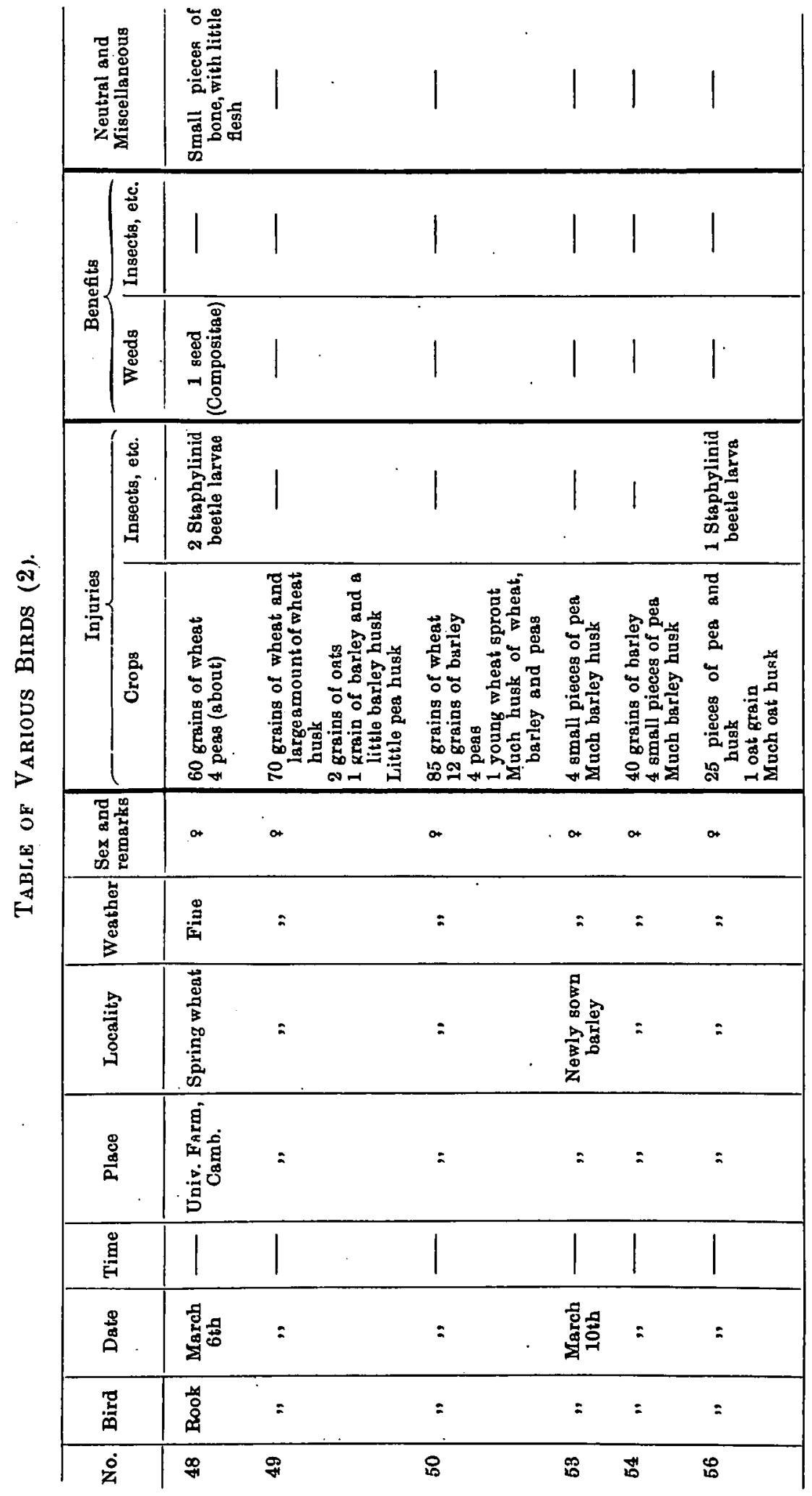


J. HAMMOND

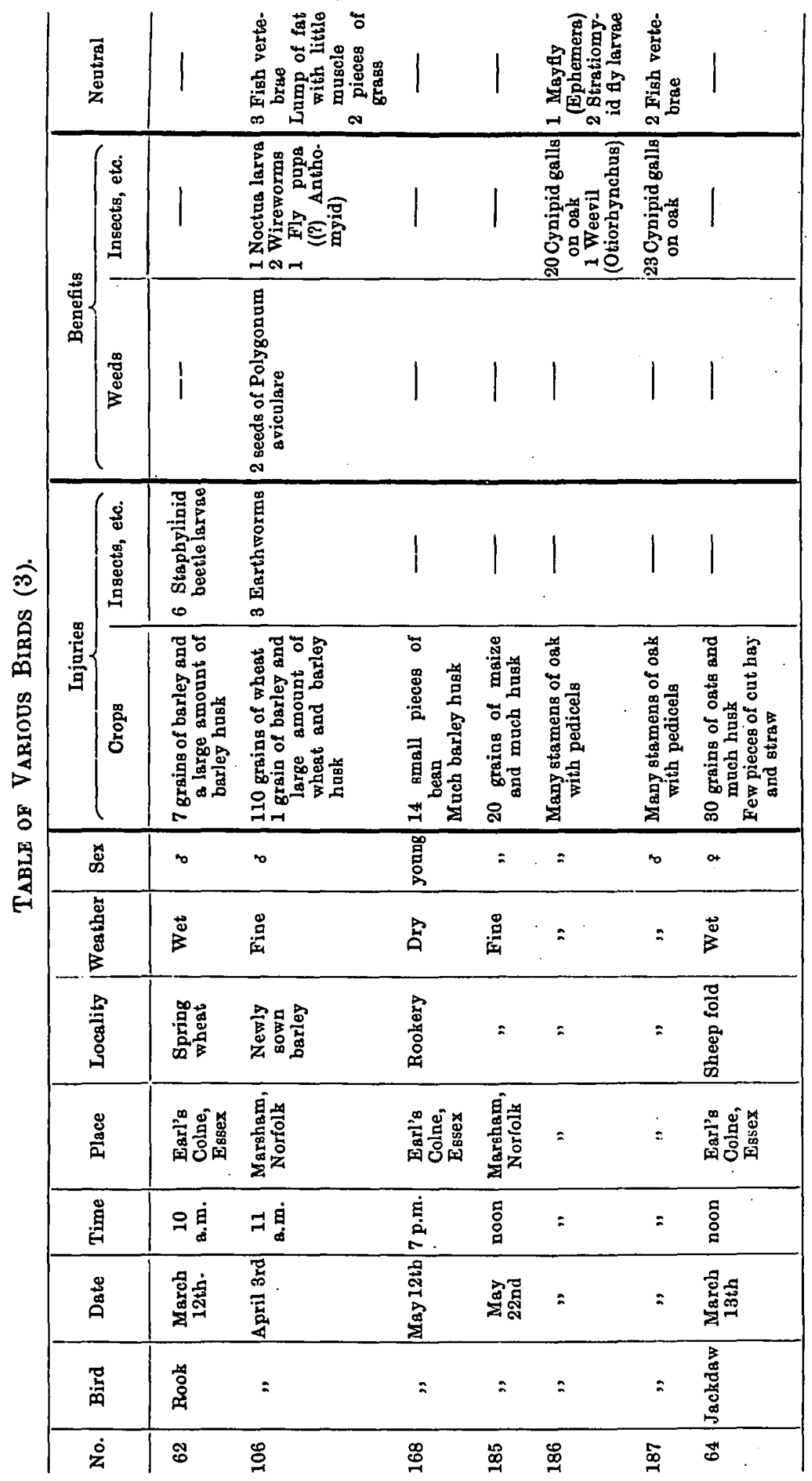




\section{Investigation concerning the Food of certain Birds}

leys and wheat is done for the most part by the migratory birds; but the damage to "small seeds" is probably done by the birds breeding here.

The conclusion reached is that, on the whole, the lark is beneficial; but, owing to the injuries done at certain times of the year, there is no reason why it should be specially protected, although its wholesale slaughter is to be deprecated.

\section{Part IV. Various Birds.}

The records of a few other birds, which were obtained at various times during the year, are given above.

An insufficient number have been obtained for an opinion to be expressed as to their utility, but it was thought that the details might be of use to others interested in the subject. In the case of rook No. 106, the wheat was probably taken from a stack, as these birds were known to have attacked one in the district.

\section{LIST OF REFERENCES.}

1. Archibald, C. F. Wild Birds, Useful and Injurious. Journ. Roy. Agric. Soo. 1892-94, and 1907.

2. ColnINar, W. E. The feeding habits of the rook Journ. Econ. Biol. vol. v. pt. 2, 1910.

3. Collinge, W. E. Some observations on the food of the starling. Second report on Economic Biology. Birmingham, 1912.

4. GIIMOOR, Sir J. Bird investigation-an enquiry concerning the relation of certain birds to the Agricultural Interest, as shown by their diet. Trans. High. and Agric. Soc. of Scotland, 1896.

5. Gurney, J. H. and Rosseis, C. A book on the House Sparrow. London, 1885 .

6. Hollnove, Dr M. Beiträge zur Bewertung der Saatkrähe auf Grund von 11-jahrigen Magenuntersuchungen. Landwirtschaftliche Jahrbilcher, 1906.

7. HOOPER, C. H. Fruit growing and bird protection. Country Gents. Estate Book, 1907.

8. HoOPER, C. H. Birds in relation to the Farm, the Orchard, the Garden and the Forest. Agric. Students Gazette, Wye, August, 1907.

9. JoDd, S. D. Methods in Economic Ornithology. Amer. Nat. vol. 31, 1897.

10. Kelso, J. E. H. Havoc wrought by Starlings. The Zoologist, 4th Series, vol. 14, 1910.

11. Mason, C. W. and Maxwell-Lefroy, H. The food of birds in India. Mem. of the Dept. of Agric. in India, 1912. 
12. Newstead, R. The food of some British birds. Supp. to the Journ. of the Board of Agric. and Fish., 1908-9.

13. Newton, A. and GADOW, H. A dictionary of birds. London, 1893.

14. PALMER, T. S. Review of Economic Ornithology in U.S.A. Yearbook of U.S. Dept. of Agric., 1899.

(This paper contains many references to work published in U.S.A.)

15. SAUNDERs, H. and Newton, A. Yarrell's British Birds. London, 1882.

16. SAWYER, W. E. Dressing for spring or winter wheat. Joumal of the Board of Agric. and Fish., Feb. 1910.

17. Slater, Rev. H. H. Wild birds and the Farm. Journ. Farmers' Club, April, 1905.

18. Thmobald, F. V. Economic Ornithology. Science Progress, July, 1907.

(A good list of references is given in this article.)

19. THORPE, L. D. and HOPE, L. E. Report on the food of the black-headed gull. Cumberland C. C., 1907.

20. The Starling. Leaflet 45. Board of Agric. and Fish. June, 1905. .

21. Report of Protection of birds in Germany. Journal of the Board of Agric. and Fish., July, 1908.

22. Experiments by the German Imperial Biol. Institute. Journal of the Board of Agric. and Fish., Dec. 1909.

NoTE. Since the above was written, Laura Florence has published a paper on "The Food of Birds" (Trans. High. and Agric. Soc. 1912) in which the crop contents of 616 birds of various species, mostly from the North East of Scotland, are described. 